\title{
ANALISIS KESULITAN MAHASISWA CALON GURU DALAM MENYUSUN LAPORAN PRAKTIKUM
}

\section{ANALYSIS OF DIFFICULTY OF TEACHER CANDIDATES IN PREPARING LABORATORY WORK REPORTS}

\author{
Yunita Arian Sani Anwar*, Syarifa Wahidah Al Idrus dan Jeckson Siahaan \\ Program Studi Pendidikan Kimia, FKIP Universitas Mataram, Mataram, Indonesia \\ Email: yunita@unram.ac.id
}

Diterima: 11 Maret 2020. Disetujui: 24 April 2020. Dipublikasikan: 30 September 2020

\begin{abstract}
Abstrak: Menulis laporan praktikum merupakan salah satu cara yang dapat digunakan untuk mengembangkan keterampilan berpikir kritis. Namun, hingga saat ini penyusunan laporan praktikum belum mendapat perhatian dalam penilaian perkuliahan. Selama ini, laporan hanya digunakan untuk memenuhi nilai praktikum sehingga feedback belum dilakukan secara optimal. Penelitian ini bertujuan untuk menganalisis kesulitan mahasiswa dalam menyusun laporan praktikum. Hasil penelitian ini diharapkan dapat menjadi bahan pertimbangan dalam memberikan mahasiswa pelatihan untuk menghasilkan tulisan yang berkualitas. Penelitian ini menganalisis laporan praktikum mahasiswa pendidikan kimia sebanyak 240 laporan yang disusun oleh mahasiswa dengan berbagai tingkatan. Komponen laporan yang dianalisis meliputi abstrak, sumber informasi, organisasi, relevansi, konten, dan presentasi. Instrumen pengumpul data menggunakan Rubrik Hoyo yang telah dimodifikasi dan dinyatakan valid oleh ahli. Hasil penelitian menunjukkan bahwa skor terendah ditunjukkan pada komponen abstrak dan organisasi sebagai komponen dengan skor tertinggi. Rata-rata seluruh komponen menunjukkan bahwa semua komponen masih tergolong rendah. Penelitian ini menyimpulkan bahwa mahasiswa masih mengalami kesulitan dalam menyusun laporan praktikum.
\end{abstract}

Kata Kunci: kemampuan menulis, mahasiswa kimia, Rubrik Hoyo

\begin{abstract}
Writing a laboratory work report is one way that can be used to develop critical thinking skills. However, until now the preparation of laboratory work reports has not received attention in the assessment of lectures. During this time, the report is only used to meet the laboratory work scores so that feedback has not been done optimally. This study aims to analyze the difficulties of students in preparing laboratory work reports. The results of this study are expected to be taken into consideration in providing training students to produce quality writing. This study analyzes the chemistry student laboratory work reports as many as 240 reports compiled by students with various levels. The report components analyzed include abstracts, sources of information, organization, relevance, content, and presentation. Data collection instruments using the Hoyo Rubric that has been modified and declared valid by experts. The results showed that the lowest score was shown in the abstract component and the organization as the component with the highest score. The average of all components shows that all components are still relatively low. This study concludes that students still have difficulty in preparing laboratory work reports.
\end{abstract}

Keywords: Writing, chemistry undergraduate students, Hoyo Rubric

\section{PENDAHULUAN}

Penyusunan laporan praktikum saat ini masih menemui beberapa kendala. Kendala yang dihadapi mahasiswa meliputi penulisan yang tidak sesuai dengan kaidah karya ilmiah, kemampuan sintesis yang masih rendah, penggunaan format yang tidak sesuai, kemampuan dalam menyusun pembahasan dan menghubungkan teori, serta penggunaan kalimat yang kurang dipahami [1]. Tingkatan kompleksitas ini menjadi pertimbangan penting dalam melatih mahasiswa membuat tulisan.

Penyusunan laporan praktikum saat ini masih memiliki banyak kelemahan di antaranya hanya menduplikasi petunjuk praktikum dan tidak melatih mahasiswa untuk membangun argumen [2,3]. Timbal balik yang diberikan oleh dosen belum dilakukan secara optimal sehingga mahasiswa belum terlatih untuk menghasilkan tulisan yang lebih baik. Padahal timbal balik yang diberikan oleh dosen akan mampu membantu mahasiswa menghasilkan laporan yang lebih baik [1,4-6].

Penulisan laporan memiliki banyak kelebihan dibandingkan menjawab pertanyaan pada saat ujian. Selain dapat membangun argumen, penyusunan laporan penyelidikan dapat melatih kemampuan berpikir kritis [7-9]. Kemampuan membahas hasil penyelidikan dalam laporan dapat menghubungkan teori yang dipelajari dengan hasil penyelidikan di laboratorium [2].

Meningkatkan kemampuan mahasiswa dalam menyusun laporan dapat dilakukan dengan melatih mereka diawali dengan komponen laporan yang paling mudah hingga komponen yang paling sulit [4]. Selain itu, feedback dosen dalam penyusunan laporan menjadi komponen penting untuk 
peningkatan kualitas sehingga mahasiswa terlatih untuk membuat tulisan yang berkualitas [6].

Penelitian ini bertujuan untuk menganalisis kesulitan mahasiswa dalam menyusun laporan praktikum. Hasil analisis ini digunakan sebagai landasan dalam melatih mahasiswa menyusun komponen laporan praktikum mulai dari komponen yang paling mudah hingga paling sulit. Hasil penelitian ini dapat juga menjadi pertimbangan dalam mengembangkan konsep praktikum yang tidak hanya melatih keterampilan laboratorium mahasiswa, namun dapat melatih keterampilan komunikasi mahasiswa dalam bentuk tulisan.

\section{METODE PENELITIAN Instrumen Penelitian}

Penelitian ini menggunakan Rubrik Hoyo [10] dalam menganalisis laporan praktikum mahasiswa. Komponen laporan yang dinilai meliputi abstrak, sumber informasi, organisasi, relevansi, konten, dan presentasi. Masing-masing komponen dikembangkan kriteria penilaian dengan skala penilaian 1-4.

\section{Teknik Analisis Data}

Penelitian ini menganalisis 240 laporan praktikum mahasiswa kimia menggunakan Rubrik Hoyo. Laporan mahasiswa mewakili laporan mahasiswa semester 1,3 dan 5 masing-masing sebanyak 80 laporan. Tingkat kesulitan mahasiswa dilihat dari rata-rata masing-masing komponen laporan dan dikonversi sesuai Tabel 1.

Tabel 1. Kategori Tingkat Kesulitan Komponen Laporan Praktikum

\begin{tabular}{lll}
\hline No & $\begin{array}{c}\text { Perhitungan masing- } \\
\text { masing komponen }\end{array}$ & \multicolumn{1}{c}{$\begin{array}{c}\text { Kategori tingkat } \\
\text { kesulitan }\end{array}$} \\
\hline 1. & $\mathrm{X} \geq X+\mathrm{SD}$ & Sangat Mudah \\
2. & $X+\mathrm{SD}>\mathrm{X} \geq X$ & Mudah \\
3. & $X>\mathrm{X} \geq X-\mathrm{SD}$ & Sulit \\
4. & $\mathrm{X}<X-\mathrm{SD}$ & Sangat Sulit \\
\hline
\end{tabular}

Keterangan: $\mathrm{X}=$ rata-rata masing komponen

$$
\begin{gathered}
X=\text { rata-rata laporan } \\
\mathrm{SD}=\text { Standar Deviasi }
\end{gathered}
$$

\section{HASIL DAN PEMBAHASAN}

Hasil penelitian menunjukkan bahwa mahasiswa masih mengalami kesulitan dalam menyusun keenam komponen laporan praktikum. Abstrak menjadi komponen dengan nilai rata-rata terendah yaitu sebesar 1,479 sedangkan komponen dengan nilai rata-rata tertinggi adalah organisasi sebesar 2,14 (Tabel 2). Urutan komponen laporan praktikum mulai dari rata-rata terendah adalah abstrak, sumber informasi, relevansi, konten, presentasi dan organisasi.

\section{Tabel 1. Rata-Rata Nilai Laporan Praktikum}

\begin{tabular}{llrl}
\hline $\begin{array}{c}\text { Komponen } \\
\text { Laporan }\end{array}$ & Rata-Rata & SD & $\begin{array}{c}\text { Kategori } \\
\text { Kesulitan }\end{array}$ \\
\hline Abstrak & 1,479 & 0,743 & Sulit \\
Sumber & 1,780 & 0,720 & Sulit \\
Informasi & & & \\
Organisasi & 2,140 & 0,580 & Mudah \\
Relevansi & 1,810 & 0,680 & Sulit \\
Konten & 1,810 & 0,674 & Sulit \\
Presentasi & 2,000 & 0,680 & Mudah \\
\hline
\end{tabular}

Komponen abstrak menjadi komponen dengan nilai rata-rata terendah pada penyusunan laporan praktikum. Analisis laporan yang disusun mahasiswa lebih banyak beranggapan bahwa abstrak sama dengan kesimpulan. Pemahaman mahasiswa tentang kata kunci juga masih rendah. Mahasiswa hanya menyalin kata kunci dari judul acara praktikum yang dilakukan.

Kriteria jumlah sumber informasi yang digunakan mahasiswa telah banyak dipenuhi ole mahasiswa. Mahasiswa menggunakan sumber informasi lebih dari 5 rujukan. Namun, penggunaan sumber informasi dari sumber primer dan bervariasi seperti artikel ilmiah, jurnal dan lainnya belum banyak yan menggunakan. Mahasiswa lebih banyak menggunakan blog atau buku saja sebagai sumber rujukan. Konsintensi penulisan rujukan belum terlihat dan ketelitian masih perlu diperhatikan. Sering terjadi mahasiswa tidak mencantumkan daftar pustaka rujukan yang digunakan atau rujukan tidak sesuai dengan daftar pustaka.

Organisasi merupakan komponen laporan dengan rata-rata nilai tertinggi dan termasuk kategori komponen yang mudah dikerjakan. Mahasiswa terlihat telah menggunakan format yang sudah disediakan meskipun beberapa mahasiswa masih ada yang tidak taat format. Kriteria yang banyak tidak terpenuhi adalah sistematika informasi yang ditampilkan belum teliti dan logis.

Relevansi dalam penulisan laporan praktikum berhubungan dengan kemampuan mengulas hasil penyelidikan yang dilakukan. Mahasiswa lebih banyak menulis kembali prosedur kerja dan hasil pengamatan. Mereka belum mampu menghubungkan hasil pengamatan dengan teori yang disusun pada tinjauan pustaka maupun teori yang telah diperoleh selama perkuliahan.

Konten terkait dengan penggunaan bahasa yang baku dan mudah dipahami. Rata-rata komponen ini termasuk pada kategori yang masih sulit dilakukan mahasiswa. Hal ini terkait dengan belum terlatihnya siswa dalam menyusun tulisan ilmiah. Penggunaan kalimat yang panjang dan tidak dipahami secara jelas sehingga masih perlu dilatihkan kepada mahasiswa.

Presentasi terkait dengan tampilan dan kerapian laporan yang dibuat oleh mahasiswa. Laporan yang disusun mahasiswa secara teknis 
masih menggunakan tulisan tangan. Secara keseluruhan mahasiswa telah menyusun laporan dengan rapi meskipun beberapa mahasiswa masih banyak yang tulisan tidak dapat dibaca.

Komponen abstrak dilaporkan sebagai komponen yang perlu banyak dilatihkan kepada mahasiswa. Persepsi mereka bahwa abstrak memiliki kesamaan isi dengan simpulan dilaporkan oleh Gupta [11] dan Hoyo [10]. Abstrak sebagai komponen tersulit dibandingkan komponen lainnya menyebabkan abstrak sebagai komponen yang paling terakhir diajarkan ke mahasiswa.

Komponen yang dirasa sulit oleh siswa berdasarkan penilaian menggunakan rubrik Hoyo adalah konten dan relevansi. Secara umum mahasiswa calon guru kurang mampu mengintegrasikan teori yang diuraikan di tinjauan pustaka dan teori yang disampaikan pada perkuliahan untuk membahas hasil penyelidikan. Beberapa peneliti mengungkapkan hal yang sama. Wackerly [1] melaporkan bahwa pembahasan adalah komponen tulisan yang memiliki tingkat kesulitan tertinggi kedua dibandingkan komponen yang lain. Ujicoba kemampuan menulis mahasiswa kimia menunjukkan bahwa hampir 80 persen mahasiswa tidak dapat memenuhi kriteria menulis pembahasan yang baik $[10,11]$.

Hasil penelitian memberikan indikasi bahwa menulis laporan belum dilatihkan pada mahasiswa calon guru. Perlu kiranya menyusun pelaksanaan praktikum yang dapat melatih kemampuan menulis mahasiswa [1,4]. Pemetaan kesulitan mahasiswa dalam menyusun laporan praktikum dapat dijadikan acuan untuk melatihkan masing-masing komponen secara berjenjang.

\section{KESIMPULAN}

Mahasiswa calon guru masih mengalami kesulitan dalam menyusun laporan praktikum. Komponen abstrak, sumber informasi, relevansi, dan konten menjadi komponen laporan penyelidikan yang paling sulit berdasarkan analisis Rubrik Hoyo. Organisasi dan presentasi menjadi komponen laporan yang dinilai mudah oleh mahasiswa.

\section{DAFTAR PUSTAKA}

[1] Wackerly, J.W. (2018). Stepwise approach to writing journal style lab reports in the organic chemistry course sequence. Journal of Chemical Education, 95(1), 76-83.

[2] Duzor, A.G.V. (2016). Using self-explanations in the laboratory to connect theory and practice: the decision/explanation/observation/inference writing method. Journal of Chemical Education, 93(10), 1725-1730.

[3] Hofstein, A., Kipnis, M., \& Kind, P. (2008). Learning in and from science laboratories: enhancing students meta-cognition and argumentation skills. In C.L. Petroselli (Ed),
Science education issues and developments (pp. 59-94). London: Nova Science.

[4] Bramer, S.E.V., \& Bastin, L.D. (2013). Using a progressive paper to develop students' writing skill. Journal of Chemical Education, 90(6), 745-750.

[5] Carr, J.M. (2013). Using a collaborative critiquing technique to develop chemistry students' technical writing skills. Journal of Chemical Education, 90(6), 751-754.

[6] JeanBurnham, J.A. (2013). Opportunistic use of students for solving laboratory problems: twelve heads are better than one. NDIR, 9(1), 42-48.

[7] Contakes, S.M. (2016). Misconduct at the lab? A performance task case study for teaching data analysis and critical thinking. Journal of Chemical Education, 93(2), 314-317.

[8] Walker, J.P. \& Sampson, V. (2013). Argumentdriven inquiry: using the laboratory to improve undergraduates' science writing skills through meaningful science writing, peer-review, and revision. Journal of Chemical Education, 90, 1269-1274.

[9] Quitadamo, I.J., \& Kurtz, M.J. (2007). Learning to improve using writing to increase critical thinking performance in general education biology. CBE-Life Sciences Education, 6, 140154.

[10] Hoyo, M.T. (2003). Designing a written assigment to promote the use of critical thinking skills in an introductory chemistry course. Journal of Chemical Education, 80 (8), 899-903.

[11]Gupta, T. (2012). Guided-inquiry based laboratory instruction: investigation of critical thinking skills, problem solving skills, and implementing student roles in chemistry. Disertasi, tidak diterbitkan, Iowa State University, Iowa. 